\title{
Ummessaolokauden ruokinnan koostumuksen vaikutus lypsylehmien insu-
}

\section{liiniresistenssiin}

\author{
Tuomo Kokkonen ${ }^{1)}$, Siru Salin ${ }^{1)}$, Kari Elo ${ }^{1)}$, Rashid Safari ${ }^{1)}$, Juhani Taponen ${ }^{2)}$, Aila Vanhatalo ${ }^{1)}$ \\ ${ }^{1)}$ Maataloustieteiden laitos, PL 28, 00014 Helsingin yliopisto \\ ${ }^{2)}$ Kliinisen tuotantoeläinlääketieteen osasto, Paroninkuja 20, 04920 Saarentaus \\ etunimi.sukunimi@helsinki.fi
}

Liian runsas energian saanti poikimista edeltävänä ummessaoloaikana nostaa veren insuliinipitoisuutta huomattavasti, mikä saattaa voimistaa kudosten insuliiniresistenssiä. Rasvakudoksen insuliiniherkkyyden väheneminen voi lisätä rasvahappojen mobilisaatiota poikimisen läheisyydessä.

Tutkimuksessa selvitettiin, miten ummessaolokauden ruokinnan energiasisältö vaikuttaa lehmien kuntoluokan kehittymiseen sekä insuliiniresistenssiin ja rasvahappojen mobilisaatioon tiineyden loppuvaiheessa ja tuotoskauden alussa.

Kokeessa oli mukana 16 vähintään toista kertaa poikivaa ay-lehmää. Lehmiä ruokittiin 8 viikon ajan ennen odotettua poikimista vapaasti joko säilörehulla tai kuitupitoisella seosrehulla. Seosrehu sisälsi $55 \%$ säilörehua, $40 \%$ olkea ja $5 \%$ rypsirouhetta kuiva-aineessa. Rypsirouhetta lisättiin seosrehuun, jotta ruokintojen raakavalkuaispitoisuus saatiin pidettyä samana (n. $120 \mathrm{~g} / \mathrm{kg} \mathrm{ka}$ ).

Tunnutusruokinnan aikana molemmat ryhmät saivat väkirehua $1 \mathrm{~kg} / \mathrm{pv}$ alkaen 10 päivää ennen odotettua poikimista. Määrä nostettiin $2 \mathrm{~kg}: \mathrm{aan} / \mathrm{pv} 5$ päivää ennen odotettua poikimista. Poikimisen jälkeen molemmilla ryhmillä oli samanlainen ruokinta. Säilörehua annettiin vapaasti ja väkirehumäärä nostettiin $16 \mathrm{~kg}: a a n / p v 32$ päivään mennessä.

Säilörehua saaneiden lehmien keskimääräinen rehun syönti kokeen alusta tunnutuskauden alkuun oli $13,1 \mathrm{~kg} \mathrm{ka} / \mathrm{pv}$ ja seosrehua saaneiden lehmien rehun syönti $11,0 \mathrm{~kg} \mathrm{ka} / \mathrm{pv}$. Säilörehua saaneet lehmät saivat keskimäärin 35 \% enemmän energiaa (MJ/pv) kuin seosrehua saaneet lehmät. Säilörehua saaneiden lehmien elopaino lisääntyi ennen tunnutusruokinnan alkua enemmän kuin seosrehua saaneiden $(1,4$ vs. $1,0 \mathrm{~kg} / \mathrm{pv}, \mathrm{p}<0,05)$. Lehmien kuntoluokassa poikimisen läheisyydessä sekä kuntoluokan ja elopainon muutoksessa poikimisen jälkeen ei ollut eroja.

Säilörehua saaneiden lehmien plasman insuliinipitoisuus $(24,3$ vs. $16,1 \mu \mathrm{IU} / \mathrm{ml}, \mathrm{p}<0,05)$ ja glukoosipitoisuus $(4,0$ vs. $3,8 \mathrm{mmol} / \mathrm{l}, \mathrm{p}<0,10)$ olivat ennen poikimista suurempia kuin seosrehua saaneiden. Plasman vapaiden rasvahappojen (NEFA) pitoisuuksissa ei ollut eroa ennen poikimista. Säilörehua saaneiden lehmien plasman glukoosipitoisuus oli poikimisen jälkeen suurempi (3,4 vs. 3,1 mmol/l, $\mathrm{p}<0,10)$ kuin seosrehua saaneiden lehmien. Plasman insuliini- ja NEFA-pitoisuuksissa ei ollut eroja.

Ennen poikimista tehdyssä glukoosirasituskokeessa $(-11 \mathrm{pv})$ säilörehua saaneiden lehmien plasman glukoosipitoisuuden käyrän alainen ala (AUC) oli pienempi (416 vs. $523 \mathrm{mmol} * \min , \mathrm{p}<0,05)$ kuin seosrehua saaneiden lehmien. Glukoosin poistumisnopeudessa ja NEFAn AUC:ssa ei ollut eroja. Insuliinin huippupitoisuus (382 vs. $230 \mu \mathrm{IU} / \mathrm{ml}, \mathrm{p}<0,05)$ ja AUC (21093 vs. $13729 \mu \mathrm{IU} * \min , \mathrm{p}<0,10)$ olivat suuremmat säilörehua saaneilla lehmillä. Poikimisen jälkeen (+8 pv) tehdyssä glukoosirasituskokeessa ei havaittu ryhmien välisiä eroja.

Runsas energian saanti ummessaolokaudella nosti veren insuliinipitoisuutta ja lisäsi lehmien elopainon kasvua, mutta ei vaikuttanut insuliiniresistenssiin tai lehmien kudosvarastojen mobilisaatioon.

Asiasanat: seosrehu, energiasisältö, insuliiniherkkyys, plasman insuliinipitoisuus, plasman glukoosipitoisuus 


\section{Johdanto}

Ruokinnan runsas energiasisältö poikimista edeltävänä ummessaoloaikana nostaa lehmien veren insuliinipitoisuutta huomattavasti (Kokkonen ym. 2004, Kokkonen ym. 2005), mikä voimistaa ääreiskudosten insuliiniresistenssiä (Holtenius ym. 2003). Runsaaseen ummessaolokauden ruokintaan liittyy tyypillisesti myös voimakas syönnin aleneminen poikimisen lähestyessä (Grummer ym. 2004), jolloin kudosten rasvavarastojen käyttö lisääntyy nopeassa tahdissa. Runsas kudosrasvan mobilisaatio lisää maksan rasvoittumista, mikä saattaa heikentää maksan glukoosin tuotantoa (Rukkwamsuk ym. 1999, Loor ym. 2006) ja maksan kykyä hapettaa rasvahappoja (Murondoti ym. 2004).

Yksilökohtaisessa ruokinnassa, mikä on tavallisin parteen kytkettyjen lypsylehmien ruokintatapa, lehmien liiallinen lihominen ja poikimista usein edeltävä syönnin aleneminen voidaan ehkäistä ruokkimalla ummessaolevia lehmiä rajoitetusti (Kokkonen ym. 2005). Pihattonavetoissa ummessaolevat lehmät ovat joko yhdessä lypsävien lehmien kanssa tai usein omana ryhmänään. Ruokinta perustuu ryhmäruokintaan ja usein seosrehun käyttöön. Vapaassa seosrehuruokinnassa lehmän ajatellaan pystyvän itse säätämään rehunsyöntiään energian ja ravintoaineiden tarpeen vaatimalle tasolle. Tutkimukset ovat kuitenkin osoittaneet, että ummessaolevat lehmät eivät vapaassa ruokinnassa säätele rehun syöntiään energian tarpeen mukaan vaan syövät usein noin 150-160 \% energian tarpeestaan (Loor ym. 2006). Liiallista energian saantia voidaan rajoittaa muokkaamalla annettavan rehuseoksen koostumusta. Kuitupitoisuutta lisättäessä fysikaalinen säätely rajoittaa kuiva-aineen syöntiä. Kuitupitoisuuden lisääminen vähentää myös dieetin energiasisältöä, mikä edelleen rajoittaa energian saantia.

Liian runsas edeltävä ruokinta ja lihavuus poikiessa voivat altistaa lehmiä tarpeettomasti metaboliselle stressille, joka lisää sairastumisriskiä ja viivästyttää lisääntymistoimintojen uudelleen käynnistymistä. Metabolisen stressin voimistuminen heikentää lehmän hyvinvointia ja lisää riskiä, että lehmä poistetaan karjasta ennenaikaisesti sairauden tai hedelmällisyysongelmien takia.

Kokeen tarkoituksena oli selvittää, millaisella yksinkertaisella, käytännön oloihin soveltuvalla ummessaoloajan ruokintamallilla voidaan vähentää lehmien metabolista stressiä poikimisen läheisyydessä ja tuotoskauden ensimmäisten viikkojen aikana. Tutkimuksen hypoteesit olivat: 1) Ennen poikimista runsaasti kuitua sisältävällä seosrehulla ruokittujen lehmien kuntoluokka on poikimisen läheisyydessä alempi ja rasvamobilisaatio on pienempää ensimmäisten tuotosviikkojen aikana kuin vapaasti säilörehua saaneiden lehmien. 2) Ennen poikimista vapaasti säilörehua saaneiden lehmien insuliiniresistenssi on voimakkaampi kuin runsaasti kuitua sisältävää seosrehua saaneiden lehmien.

\section{Aineisto ja menetelmät}

Kokeessa oli mukana 16 vähintään toisen kerran poikivaa ay-lehmää. Koe alkoi 8 viikkoa ennen odotettua poikimispäivää ja päättyi 8 viikkoa poikimisen jälkeen. Ummessaolokauden ajan sekä 8 pv ajan poikimisen jälkeen lehmät pidettiin parsissa, minkä jälkeen lehmät siirrettiin pihattoon. Lehmät siirrettiin poikimakarsinaan aikaisintaan 3 vuorokautta ennen odotettua poikimispäivää. Poikimisen jälkeen lehmät siirrettiin takaisin samaan parsipaikkaan, jossa ne olivat ennen poikimista.

Koemuoto oli täydellisesti satunnaistettu lohkokoe, jossa lehmät jaettiin pareihin kuntoluokituksen ja odotetun poikimapäivän perusteella. Kunkin parin lehmät arvottiin koeruokinnoille. Lehmä saivat ummessaolokauden ajan, alkaen 8 viikkoa ennen odotettua poikimista, vapaasti säilörehua (säilörehu) tai vapaasti kuitupitoista seosrehua (seosrehu). Säilörehuryhmän lehmät saivat 2. sadon säilörehua. Seosrehu sisälsi $55 \%$ 1. sadon säilörehua, $40 \%$ olkea ja $5 \%$ rypsirouhetta kuiva-aineessa. Rypsirouhetta lisättiin seosrehuun, jotta ruokintojen raakavalkuaispitoisuus saatiin pidettyä samana (n. $120 \mathrm{~g} / \mathrm{kg} \mathrm{ka}$ ).

Tunnutusruokintana lehmät saivat väkirehua (PRO-Maituri 20, RehuRaisio Oy) 10 päivän ajan ennen poikimista siten, että ensimmäisten $5 \mathrm{pv}$ annos oli $1 \mathrm{~kg} / \mathrm{pv}$ ja seuraavien $5 \mathrm{pv}$ annos $2 \mathrm{~kg} / \mathrm{pv}$. Lisäksi lehmät saivat Tunnumelli-kivennäistä (RehuRaisio Oy) 200g/pv. Poikimisen jälkeen molempien ryhmien ruokinta oli samanlainen. Lehmille annettiin vapaasti säilörehua. Päivittäisen täysväkirehun (PRO-Maituri 20, RehuRaisio Oy) ja puolitiivisteen (Amino-Maituri 30, RehuRaisio Oy) määrää lisättiin poikimisen jälkeen siten, että väkirehumäärä nostettiin $16 \mathrm{~kg}$ :aan/pv 32 päivään mennessä. Lisäksi lehmät saivat Pihattomelli-kivennäistä (RehuRaisio Oy) 200g/pv.

Lehmät punnittiin 56, 42, 28, 14, ja 5 päivää ennen odotettua poikimista sekä 1, 2, 6, 7, 14, 28, 42 ja 56 päivää poikimisen jälkeen. Jos poikiminen viivästyi, punnitus uusittiin 5 pv välein. Ennen 
poikimista lehmät kuntoluokitettiin samoina ajankohtina kuin punnittiin. Poikimisen jälkeen lehmät kuntoluokitettiin 1, 7, 14, 28, 42 ja 56 päivää poikimisesta. Lehmien rehun syönti mitattiin päivittäin punnitsevien ruokintakuppien (Insentec B.V., Marknesse, Alankomaat) avulla.

Lehmiltä otettiin verinäytteitä häntäsuonesta $56,42,28,21,16,12,7,5,3$ ja 1 päivää ennen odotettua poikimista sekä 1, 3, 5, 14, 21, 28, 42 ja 56 päivää poikimisen jälkeen. Lehmille tehtiin glukoosirasituskokeet $11(+/-1)$ päivää ennen odotettua poikimista ja $8(+/-1)$ päivää poikimisen jälkeen. Rasituskoe suoritettiin infusoimalla vasempaan kaulalaskimoon asetetun katetrin kautta glukoosia suoneen $(0,25$ g/elopainokilo) ja keräämällä verinäytteitä oikeaan kaulalaskimoon asetetun katetrin kautta $-10,-5,0,1,2,3,4,5,6,7,8,10,12,14,16,18,20,22,24,26,28,30,40,50,60,70,80,90$, $120,150,180,210$ ja $240 \mathrm{~min}$ kuluttua infuusion alkamisesta. Katetrit asetettiin paikalleen glukoosirasituskoetta edeltävänä päivänä. Kaikista verinäytteistä määritettiin glukoosi, insuliini ja NEFA.

Glukoosirasituskokeiden NEFA-, glukoosi- ja insuliinipitoisuuksista laskettiin SASohjelmistoon (versio 9.1) luodun makron avulla puolisuunnikasmenetelmää käyttäen perustason ylätai alapuolelle jäävän pitoisuus-aikakäyrän alainen pinta-ala (AUC). Pitoisuuksien perustasona käytettiin 15 ja 5 min ennen glukoosi-infuusiota otettujen verinäytteiden pitoisuuksien keskiarvoa. Glukoosin poistumisnopeuden (CR, \%/min) laskemiseksi pitoisuuksiin sovitettiin ensin SAS:n NLINproseduurilla eksponentiaalinen malli $\mathrm{F}(\mathrm{t})=\mathrm{A} * \mathrm{e}^{\left(-\mathrm{k}^{*} \mathrm{t}\right)}$, missä $\mathrm{A}$ on glukoosin estimoitu huippupitoisuus, $\mathrm{k}$ on regressiokerroin ja t on aika. Mallin tulosten perusteella laskettiin poistumisnopeus kaavalla: $\mathrm{CR}=100 *(\ln [\mathrm{ta}]-\ln [\mathrm{tb}]) /(\mathrm{tb}-\mathrm{ta})$, missä [ta] ja [tb] ovat pitoisuudet ajan hetkellä a ja b.

Tulosten tilastollisessa analyysissa käytettiin SAS-ohjelmiston (versio 9.2) Mixed-proseduuria. Häntäsuonesta otettujen verinäytteiden tulokset analysoitiin käyttäen toistettujen mittausten mallia. Kiinteinä tekijöinä mallissa olivat ruokinta, aika ja ruokinnan ja ajan yhdysvaikutus, ja satunnaisina tekijöinä pari sekä parin ja ajan yhdysvaikutus. Kunkin lehmän havaintoihin sovitettiin kolme eri kovaranssirakennetta: CS, UN ja SP(POW). Glukoosirasituskokeiden tulokset sekä elopaino- ja kuntoluokkatulokset analysoitiin käyttäen mallia, jossa oli kiinteänä tekijänä ruokinnan vaikutus ja satunnaisena tekijänä pari. Ennen poikimista tehtyjen glukoosirasituskokeiden tuloksia analysoitaessa malliin lisättiin kiinteänä tekijänä aikaväli rasituskokeesta toteutuneeseen poikimiseen. Elopainon muutos ennen poikimista ei ollut normaalijakautunut, joten se analysoitiin Friedmanin kaksisuuntaisella eiparametrisella varianssianalyysilla.

\section{Tulokset ja tulosten tarkastelu}

Säilörehua saaneiden lehmien keskimääräinen rehun syönti kokeen alusta tunnutuskauden alkuun oli $13,1 \mathrm{~kg} \mathrm{ka} / \mathrm{pv}$ ja seosrehua saaneiden lehmien rehun syönti $11,0 \mathrm{~kg} \mathrm{ka} / \mathrm{pv}$. Säilörehu keskimääräinen energiasisältö oli 10,4 MJ/kg ka ja seosrehun 9,2 MJ/kg ka. Suuremman päivittäisen rehun syönnin ja rehuannoksen suuremman energiasisällön ansiosta säilörehua saaneet lehmät saivat keskimäärin $35 \%$ enemmän energiaa $(\mathrm{MJ} / \mathrm{pv})$ kuin seosrehua saaneet lehmät.

Vapaasti säilörehua saaneiden lehmien elopaino kasvoi kuuden viikon jaksolla ennen tunnutusruokinnan aloittamista keskimäärin $1,4 \mathrm{~kg} / \mathrm{pv}$. Seosrehua saaneiden lehmien elopaino kasvoi vastaavalla aikavälillä 1,0 kg/pv (Taulukko 1). Lypsylehmien ruokintasuositusten (MTT2011) mukaan säilörehua saaneiden lehmien suurempi energiansaanti olisi riittänyt noin $1 \mathrm{~kg} / \mathrm{pv}$ suurempaan elopainon lisäykseen kuin seosrehua saaneiden lehmien energian saanti. Ero ruokintaryhmien elopainon kasvussa oli siten odotettua pienempi. Myös Salinin ym. (2012) tutkimuksessa havaittiin, että vastaavan suuruinen ero vapaasti ja energiantarpeen mukaan rajoitetusti säilörehulla ruokittujen lehmien energian saannissa lisäsi elopainon kasvua odotettua vähemmän. Sen sijaan Kokkosen ym. (2005) tutkimuksessa elopainon kasvu lisääntyi laskennallisen energian saannin ennustamalla tavalla, kun osa yliruokittujen saamasta lisäenergiasta oli peräisin täysväkirehusta.

Kuntoluokan muutokset ummessaolokauden aikana (Taulukko 1) olivat melko pieniä molemmissa ruokintaryhmissä. Myös Kokkonen ym. (2005) ja Salin ym. (2012) havaitsivat, että lisääntyneen energiansaannin vaikutus kuntoluokan muutokseen ummessaolokauden aikana on vähäinen. Osittain odotettua vähäisempiä eroja kuntoluokan muutoksissa voi selittää ero vasikoiden painoissa (Salin ym. 2012). Tässä tutkimuksessa vasikoiden painoissa ei ollut eroa ryhmien välillä.

Olettaen, että sikiön kasvun osuus elopainon lisäyksestä ummessaolokauden aikana on $35-40 \mathrm{~kg}$ (NRC 2001, Douglas ym. 2006), seosrehulla ruokittujen lehmien elopainon lisäys ennen poikimista on todennäköisesti suuntautunut lähes täysin vasikan kasvuun. Myös energian suuntautuminen muualle kuin nahanalaiseen rasvakudokseen voi selittää runsaammin ruokittujen lehmien odotettua pienempää 
kuntoluokan muutosta. Osa runsaamman ruokinnan sisältämästä lisäenergiasta voi suuntautua ruoansulatuskanavan alueen rasvakudoksiin, joiden muutosta ei kuntoluokituksen avulla pystytä arvioimaan.

Taulukko 1. Elopainot ja kuntoluokat

\begin{tabular}{lcccc}
\hline & Säilörehu & Seosrehu & SEM & $\begin{array}{c}\text { Merkitsevyys } \\
\text { Ruokinta }\end{array}$ \\
\hline Elopaino ennen poikimista & & & & \\
$\quad$ Kokeen alussa, kg & 726 & 740 & 42,1 & \\
2 vk ennen poikimista, $\mathrm{kg}$ & 786 & 781 & 38,7 & $*$ \\
Elopainon muutos, kg/pv & 1,4 & 1,0 & 0,16 & \\
& & & & \\
Elopaino poikimisen jälkeen & 718 & 719 & 39,8 & \\
1 - 2 pv poikimisen jälkeen, kg & 692 & 700 & 35,3 & \\
8 vk poikimisen jälkeen, kg & $-0,75$ & $-0,62$ & 0,26 \\
Elopainon muutos, kg/pv & & & & \\
& & & & \\
Kuntoluokka & 3,4 & 3,5 & 0,20 \\
Kokeen alussa & 3,7 & 3,7 & 0,20 \\
5 pv ennen poikimista & 3,1 & 2,9 & 0,21 \\
8 vk poikimisen jälkeen & & &
\end{tabular}

Säilörehua saaneiden lehmien plasman insuliinipitoisuus $(\mathrm{p}<0,05)$ ja glukoosipitoisuus $(\mathrm{p}<0,10)$ olivat ennen poikimista suurempia kuin seosrehua saaneiden (Taulukko 2). Energian saannin lisääminen on kasvattanut veren insuliinipitoisuutta myös aiemmissa ummessaolokauden ruokintatutkimuksissa (Holtenius ym. 2003, Douglas ym. 2006, Salin ym. 2012). Energian saannin lisäämisen vaikutus veren glukoosipitoisuuteen ei ole ollut yhtä johdonmukainen kuin vaikutus insuliinipitoisuuteen. Joissakin tutkimuksissa runsaampi energian saanti on kasvattanut veren glukoosipitoisuutta (Holtenius ym. 2003, Douglas ym. 2006, Winkelman ym. 2008), toisissa vaikutusta ei ole havaittu (Kunz ym. 1985, Salin ym. 2012). Energian saannin rajoittaminen ei tässä tutkimuksessa kasvattanut plasman NEFApitoisuutta ennen poikimista, toisin kuin Salinin ym. (2012) tutkimuksessa, jossa havaittiin lievä nousu plasman NEFA-pitoisuudessa ummessaolokaudella.

Taulukko 2. Plasman glukoosi-, NEFA- ja insuliinipitoisuudet

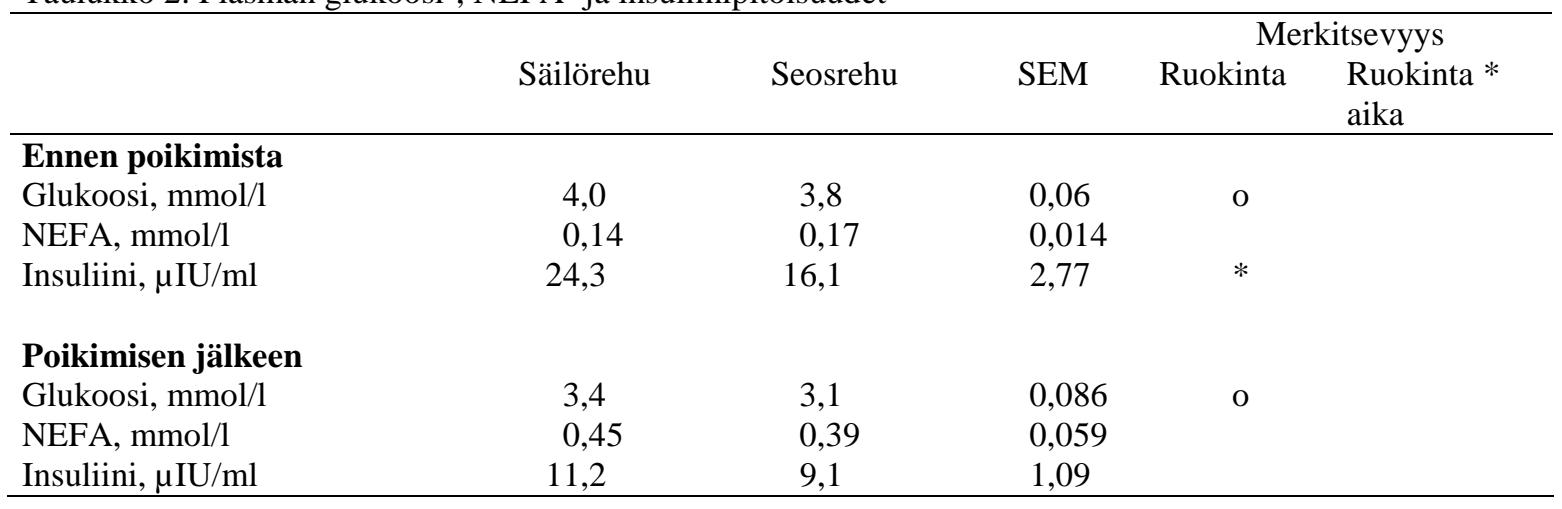

Molemmissa ruokintaryhmissä plasman glukoosipitoisuudet pienenivät poikimisen jälkeen, mutta säilörehua saaneiden lehmien plasman glukoosipitoisuus oli edelleen suurempi $(\mathrm{p}<0,10)$ kuin seosrehua saaneiden. Myös Winkelman ym. (2008) havaitsivat ummessaolokauden runsaamman energiaruokinnan lisäävän plasman glukoosipitoisuutta poikimisen jälkeen. Toisaalta useissa muissa tutkimuksissa (Holtenius ym. 2003, Douglas ym. 2006, Salin ym. 2012) vastaavaa eroa ei ole havaittu.

Plasman insuliinipitoisuus väheni molemmissa ryhmissä viimeisen poikimista edeltävän viikon aikana. Samanaikaisesti plasman NEFA-pitoisuus kasvoi, mikä osoittaa rasvahappojen mobilisaation rasvakudoksesta käynnistyneen. Rasvamobilisaation käynnistyminen ei ollut yhteydessä energiataseeseen, koska NEFA-pitoisuus kasvoi molemmissa ryhmissä samalla tavalla, vaikka energian saannissa oli edelleen selvä ero ryhmien välillä. Poikimisen jälkeen plasman insuliipitoisuuksissa ei ollut eroa ruokintaryhmien välillä, yhtäpitävästi aiempien tutkimusten kanssa (Holtenius ym. 2003, Douglas ym. 
2006, Salin ym. 2012). Runsas ummessaolokauden ruokinta on joissakin aiemmissa tutkimuksissa (Holtenius ym. 2003, Douglas ym. 2006) lisännyt rasvahappojen mobilisaatiota ja kasvattanut plasman NEFA-pitoisuutta poikimisen jälkeen. Näissä tutkimuksissa erot energian saannissa ummessaolokauden ruokintaryhmien välillä ovat olleet suurempia kuin tässä tutkimuksessa ja osa lisäenergiasta on ollut peräisin väkirehusta. Myös kuntoluokkien erot poikimisen lähellä ovat olleet suurempia kuin tässä kokeessa.

Ennen poikimista tehdyssä glukoosirasituskokeessa vapaasti säilörehua saaneiden lehmien glukoosin AUC oli pienempi kuin seosrehua saaneiden (Taulukko 3). Glukoosin AUC:n pieneneminen viittaa ääreiskudosten suurempaan kykyyn käyttää glukoosia. Toisaalta säilörehua saaneiden lehmien insuliinin AUC oli suurempi glukoosirasituskokeen aikana kuin seosrehua saaneiden. Runsaampi energian saanti vapaalla säilörehuruokinnalla lisäsi siis glukoosin stimuloimaa insuliinin eritystä glukoosirasituskokeessa. Näin ollen säilörehulla ruokittujen lehmien glukoosin AUC:n pienenemiseen vaikutti todennäköisesti ensisijaisesti suurempi veren insuliinipitoisuus glukoosirasituskokeen aikana, jolloin ääreiskudosten insuliiniherkkyydessä ei ilmeisesti ollut eroa ryhmien välillä. Myös Holtenius ym. (2003) havaitsivat, että runsaampi ummessaolokauden ruokinta lisäsi glukoosin stimuloimaa insuliinin eritystä glukoosirasituskokeessa, jolloin glukoosin poistumisnopeus kasvoi. Sen sijaan Salinin ym. (2012) tutkimuksessa ummessaolokauden energian saanti ei vaikuttanut glukoosin poistumisnopeuteen tai AUC:hen. Toisin kuin tässä tutkimuksessa, Salinin ym. (2012) kokeessa ummessaolokauden energian saannin rajoittaminen kasvatti NEFAn AUC:n itseisarvoa, mikä viittasi lisääntyneeseen rasvakudoksen insuliiniherkkyyteen.

Taulukko 3. Glukoosirasituskoe ennen poikimista (-11 pv)

\begin{tabular}{|c|c|c|c|c|}
\hline & Säilörehu & Seosrehu & SEM & $\begin{array}{l}\text { Merkitsevyys } \\
\text { Ruokinta }\end{array}$ \\
\hline Glukoosi, perustaso, $\mathrm{mmol} / \mathrm{l}$ & 4,1 & 3,9 & 0,12 & \\
\hline Glukoosi, huippupitoisuus, mmol/l & 19,2 & 19,4 & 0,37 & \\
\hline Glukoosi, poistumisnopeus, $\% / \mathrm{min}$ & 1,3 & 1,3 & 0,10 & \\
\hline Glukoosi, AUC240, mmol/1 x $240 \mathrm{~min}$ & 416 & 523 & 49,1 & * \\
\hline Insuliini, perustaso, $\mu \mathrm{IU} / \mathrm{ml}$ & 15,6 & 13,9 & 2,1 & \\
\hline Insuliini, huippupitoisuus, $\mu \mathrm{IU} / \mathrm{ml}$ & 382 & 230 & 70,4 & $*$ \\
\hline Insuliini, AUC240, $\mu \mathrm{IU} / \mathrm{ml}$ x $240 \mathrm{~min}$ & 21093 & 13729 & 3734,5 & o \\
\hline NEFA, perustaso, mmol/1 & 0,25 & 0,36 & 0,060 & \\
\hline NEFA, AUC60, mmol/1 x $60 \mathrm{~min}$ & $-2,3$ & $-4,4$ & 1,71 & \\
\hline
\end{tabular}

Poikimisen jälkeen tehdyn glukoosirasituskokeen tarkoituksena oli selvittää, lisäsikö ummessaolokauden runsas energiaruokinta insuliiniresistenssiä siten, että voimistunut insuliiniresistenssi oli havaittavissa myös poikimisen jälkeen, jolloin kaikkia lehmiä ruokittiin samalla tavalla. Glukoosirasituskokeen tulosten (Taulukko 4) perusteella ruokintaryhmien insuliiniresistenssissä ei ollut eroa, koska mitatuissa muuttujissa ei ollut ryhmien välisiä eroja. Myöskään Salinin ym. (2012) tutkimuksessa ummessaolokauden energian saanti ei vaikuttanut glukoosirasituskokeen tuloksiin 10 päivää poikimisen jälkeen. Holtenius ym. (2003) havaitsivat, että ummessaolokauden yliruokinta vähensi glukoosin poistumisnopeutta 3 viikkoa poikimisen jälkeen tehdyssä rasituskokeessa, vaikka insuliinipitoisuuksissa ja lehmien maitotuotoksissa ei ollut eroa ruokintaryhmien välillä. Erot ummessaolokauden ruokintatasoissa ja havaituissa kuntoluokkaeroissa selittävät tutkimustulosten välisiä eroja, koska Holteniuksen ym. (2003) tutkimuksessa energian saannin erot ja havaitut kuntoluokkaerot ummessaolokaudella olivat suurempia kuin tässä tai Salinin ym. (2012) tutkimuksessa. 
Taulukko 4. Glukoosirasituskoe poikimisen jälkeen (+8 pv)

\begin{tabular}{|c|c|c|c|c|}
\hline & Säilörehu & Seosrehu & SEM & $\begin{array}{l}\text { Merkitsevyys } \\
\text { Ruokinta }\end{array}$ \\
\hline Glukoosi, perustaso, $\mathrm{mmol} / \mathrm{l}$ & 3,1 & 3,0 & 0,16 & \\
\hline Glukoosi, huippupitoisuus, $\mathrm{mmol} / \mathrm{l}$ & 16,8 & 15,5 & 0,55 & \\
\hline Glukoosi, poistumisnopeus, $\% / \mathrm{min}$ & 1,9 & 1,6 & 0,15 & \\
\hline Glukoosi, AUC240, mmol/l x $240 \mathrm{~min}$ & 322 & 374 & 30,1 & \\
\hline Insuliini, perustaso, $\mu \mathrm{IU} / \mathrm{ml}$ & 5,7 & 6,2 & 0,75 & \\
\hline Insuliini, huippupitoisuus, $\mu \mathrm{IU} / \mathrm{ml}$ & 125 & 109 & 17,4 & \\
\hline Insuliini, AUC240, $\mu \mathrm{IU} / \mathrm{ml}$ x $240 \mathrm{~min}$ & 5263 & 4524 & 643,9 & \\
\hline NEFA, perustaso, mmol/l & 0,62 & 0,53 & 0,069 & \\
\hline NEFA, AUC60, mmol/1 x $60 \mathrm{~min}$ & $-7,9$ & $-5,2$ & 2,05 & \\
\hline
\end{tabular}

\section{Johtopäätökset}

Runsas energian saanti ummessaolokaudella nosti veren insuliinipitoisuutta ja lisäsi lehmien elopainon kasvua, mutta ei vaikuttanut lehmien kuntoluokkaan. Ummessaolokauden ruokinnan energiasisällöllä ei ollut vaikutusta insuliiniresistenssiin tai lehmien kudosvarastojen mobilisaatioon

\section{Kirjallisuus}

Douglas, G.N., Overton, T.R., Bateman, H.G., Dann, H.M. \& Drackley, J.K. 2006. Prepartal plane of nutrition, regardless of dietary energy source, affects periparturient metabolism and dry matter intake. Journal of Dairy Science 89: 2141-2157.

Holtenius K., Agenäs, S., Delavaud, C. \& Chilliard, Y. 2003. Effects of feeding intensity during the dry period. 2. Metabolic and hormonal responses. Journal of Dairy Science 86: 883-891.

Grummer, R.R., Mashek, D.G. \& Hayirli, A. 2004. Dry matter intake and energy balance in the transition period. Veterinary Clinics of North America: Food Animal Practice 20: 447-470.

Kokkonen, T., Taponen, J., Anttila, T., Syrjälä-Qvist, L., Delavaud, C., Chilliard, Y., Tuori, M. \& Tesfa, A.T. 2005. Effect of body fatness and glucogenic supplement on lipid and protein mobilization and plasma leptin in dairy cows. Journal of Dairy Science 88: 1127-1141.

Kokkonen, T., Tesfa, A.T., Tuori, M. \& Syrjälä-Qvist, L. 2004. Concentrate feeding strategy of dairy cows during transition period. Livestock Production Science 86: 239-251.

Kunz, P.L., Blum, J.W., Hart, I.C., Bickel, H. \& Landis, J. 1985. Effects of different energy intakes before and after calving on food intake, performance and blood hormones and metabolites in dairy cows. Animal Production 40: 219-231.

Loor, J.J., Dann, H.M., Janovick Guretzky, N.A., Everts, R.E., Oliveira, R., Green, C.A., Litherland, N.B., Rodriguez-Zas, S.L., Lewin H.A. \& Drackley, J.K. 2006. Plane of nutrition prepartum alters hepatic gene expression and function in dairy cows as assessed by longitudinal transcript and metabolic profiling. Physiological Genomics 27: 29-41.

NRC. 2001. Nutrient Requirements of Dairy Cattle. National Research Council. 7th rev. ed. National Academy Press, Washington, DC.

MTT 2011. Rehutaulukot ja ruokintasuositukset. Maa- ja elintarviketalouden tutkimuskeskus. Saatavissa internetissä: https://portal.mtt.fi/portal/page/portal/Rehutaulukot.

Murondoti, A., Jorritsma, R., Beynen, A.C., Wensing, T. \& Geelen, M.J.H. 2004. Unrestricted feed intake during the dry period impairs the postpartum oxidation and synthesis of fatty acids in the liver of dairy cows. Journal of Dairy Science 87: 672-679.

Rukkwamsuk, T., Wensing, T. \& Geelen, M.J.H. 1999. Effect of fatty liver on hepatic gluconeogenesis in periparturient dairy cows. Journal of Dairy Science 82: 500-505.

Salin, S., Elo, K., Pursiainen, P., Taponen, J., Vanhatalo, A. \& Kokkonen, T. 2012. Ummessaolokauden energiansaannin vaikutus lypsylehmien aineenvaihdunnan säätelyyn, syöntiin ja maitotuotokseen. Maataloustieteen päivät 2012.

Winkelman, L.A., Elsasser, T.H. \& Reynolds, C.K. 2008. Limit feeding a high-energy diet to meet energy requirements in the dry period alters plasma metabolite concentrations but does not affect intake or milk production in early lactation. Journal of Dairy Science 91:1067-1079. 